\title{
The available situation of meadows in Şanlıurfa and the usage areas of useful and harmful plants
}

\author{
Ayşe Çalık \\ Department of Field Crops, Faculty of Agriculture, Harran University, 63300 Şanliurfa, Turkey
}

Corresponding author: aysgns@yahoo.com

\begin{abstract}
Meadows and grasslands are one of the most important natural resources in the region. These areas are the cheapest sources of production where our need for animal nutrition is met, as well as where the need for roughage is met so that animals can produce high yields. As a result of continuous excessive and uncontrolled grazing of meadows and grasslands, losses have occurred in the existing vegetation cover. These areas are covered with plant communities where animals do not eat and have difficulty in digestion. To correct this situation and take necessary measures, a vegetation study was carried out in 2016. In the study carried out in the single and fatik mountains representing the city of Şanliurfa, vegetation study was carried out with the wheel point method and it was studied in 12 determined areas. According to the results of the study, $32 \%$ of the pastures are covered with plants, while the remaining part is devastated by overgrazing and drought. Nowadays, plants that grow spontaneously in meadows and pastures are the food sources consumed by people in various ways. Plants that are beneficial according to the structure and properties of the plants collected by humans have been used by people for making food rather than medicine. Some of the plants have a poisonous effect and if the animals consume, the damage occurs. Useful and harmful plant species rates were determined as $19.3 \%$ and $32.5 \%$, respectively. Poisonous herbs cause anorexia in animals, irreversible problems in excessive use, and even cause their death. As a result, the plants that are beneficial and harmful to human health in the meadow pastures of Şanliurfa province, the existence of these plants should be protected and their properties and use should be explained to people, both medically and as a food. It was concluded that the pastures in two different mountains in Şanlıurfa province were degraded due to overgrazing and that they should be urgently protected by applying appropriate breeding methods.
\end{abstract}

Key words: Meadow, grassland, useful, harmful, content, ingredients.

\section{Introduction}

Meadows and pastures are of great importance for the future and the continuity of life (Stewart and Pullin 2008). In our Country, Meadows and pastures are very important sources of roughage in animal nutrition and are areas with rich vegetation. These areas where forage crops are grown are described as areas where quality roughage is plentiful and the cheapest is met (Streeter et al. 1974). Meadows and pastures contain wild relatives, which are the source of genes for many cultivated plants, but are also the source of genes for many medicinal plants (Sargin 2015, Çakır 2017). According to the Agricultural Census data of the Turkish Statistical Institute, there are 14,611,920 ha of meadows and pastures in our country. In terms of these areas, south east Anatolia region has 996,230 ha and this area has approximately $14.66 \%$ of Turkey's Prairie pasture areas. According to the 2013 data of the Provincial Directorate of Agriculture in Sanliurfa, it has a meadow and pasture area of 234,357 ha. 
One of the most important problems of Meadow and pasture areas is the presence of weeds (Perry and Galatowitsch 2006). Weeds have become a problem as a result of excessive and uncontrolled grazing of pastures (Belsky and Gelbard 2000). A large proportion of rapidly growing weeds are of plants that animals reluctantly eat, have difficulty eating, and sometimes even contain toxic substances (Williams 1980). The vast majority of these poisonous plants cause problems for grazing animals because of the various alkaloids and other organic chemical compounds they contain (Ismail et al. 2012). Some species of spiny weeds in these areas cause injury to animals, while poisonous species make good evaluation of weed difficult and lead to anorexia, causing negative effects such as poor quality. When these plants are consumed too much, they cause animals to be poisoned, making it difficult to save those who are poisoned, often resulting in death. In order to minimize toxic plant damage in terms of animal health and animal production, it is necessary to recognize plants containing toxic substances, to know their botanical structure and properties and to introduce them to producers benefiting from pastures.

Since the discovery of self-growing weeds in meadows pastures, these weeds have become indispensable for the people living in the countryside. These foreign plants are used to meet various needs of humans as well as to feed animals. They recognized the plants they considered useful, introduced them and used them to treat diseases (Lentini 2000). Many food varieties have included these plants. They have collected these plants and sold them in the market by yesilding them or by drying them. In this way it has become a source of income for some segments. Sometimes unwanted situations can arise due to improper use of plants. Therefore, it is very important to know the way plants influence people's culture and experiences, how they use, Apply These plants, and how they express them in Information Systems. This study focuses on determining the effects of spontaneous plants grown on the meadow pastures of Şanliurfa province, plants collected and consumed by humans, on humans and animals.

\section{Material and Methods}

\section{Used in the study process and method}

In determining the producers participating in the questionnaire, the following 'was used in order to determine the number of producers who are included in the sample and the probability of being an example for all producers (Arıkan, 2007).

$$
n=\frac{N p(1-p)}{(N-1) O-2 P x+p(1-p)}
$$

Formula 1

\section{Wild plants that grow spontaneously in nature}

For centuries, people have struggled to adapt to the natural conditions of life. This enabled people to sustain wildlife, hunt and use wild plants that grow naturally in Prairie pastures to sustain their lives. In both medical and food fields, people constantly needed wild plants in nature. They also treated these wild plants as vegetables and used them in their meals to meet their nutritional needs. Some wild plants that grow naturally in meadows and pastures have a positive or negative effect on animals such as humans. This is because plants contain toxic substances and they cause various problems on animals. If we divide the plants into two as beneficial and harmful, some of the major plants that grow spontaneously in the meadows and pastures of Şanlıurfa province are beneficial or harmful. 


\section{A. Beneficial plants growing in the meadows and pastures of Şanlıurfa and their properties 1-Purslane (Portulacca oleraceae)}

It is a single annual herbaceous plant belonging to the group of pursotugiller family, which can extend up to $30 \mathrm{~cm}$ and its body is lying on the soil, its leaves are sessile and fleshy. The most consumed part is small, round Yesil leaves and young stems. The small flowers of the plant are usually yellow, sometimes magenta, pink or red in color. The fruits of this plant contain a large number of small black seeds. It tastes a little sour.

\section{Benefits:}

Purslane protects heart health and is effective in preventing cancer.

Rejuvenates skin, strengthens bones and immune system,

It is good for some digestive system diseases.

It is a plant that dieters can easily consume because it is low in calories (Uddin et al. 2014).

\section{2-Kenger (Gundelia tournefortii)}

Kenger is a perennial, milky and spiny herbaceous plant belonging to the family of daisies, $70-80 \mathrm{~cm}$ tall. April-May begins to flower. The flowers are purplish red and the head gets a yellowish green color in maturity. It is a spiny and medicinal plant that grows spontaneously in high places, in steep rocky areas of the mountains. He likes a dry climate. Its seeds can be grown in arid and gravelly soils.

\section{Benefits:}

The seeds of kenger Thorn can be consumed by mixing with honey or molasses. It is good for dental diseases and diabetes.

It is effective in relieving anemia and malaise (Barman and Bhattacharjee 2019).

\section{3-Hibiscus (Malva sylvestris)}

The common name of the plant is Mallow, which contains up to 1500 species of the same genus in the mallow family. They are two or perennial herbaceous plant species. Its leaves are round-shaped, edges toothed, long-stalked, hairy, 3-7 segmented and veined like palm. It has pink-colored, magenta-striped flowers that open at the end of summer and early autumn, and the flowers emerge from the seats of the leaves.

\section{Dishes made with hibiscus}

It is also used in steamed (bulgur rice with hibiscus), Mallow wrap, Mallow charcoal roasting, Mallow roasting, pies and salads.

\section{Benefits:}

Provides comfort in breathing and stops coughing.

Makes the effect of reducing fever. It's good for the cold and bronchitis.

Removes nosebleeds and congestion.

It is effective against stomach pains and nausea, which are the leading cause of stomach problems (Anuradha et al. 2018).

Cuts gingival bleeding. It strengthens the immune system. It is effective in removing hoarseness, throat disorders and tonsillitis to a large extent. 
Softens and moisturizes the skin against the dryness of the skin. Detention is good for wrinkles and swelling.

\section{4-Stinger (Urticadioica)}

It is a plant in the family of nettles and is $20-100 \mathrm{~cm}$ tall. It is a single annual herbaceous plant that grows on roadsides and Wall bottoms. Its body is erect, 4-pointed, simple or branched from the base. The plant has Burning hairs on it. The leaves are stalked, oval shaped and toothed edged, the upper side is dark green in color and bright, covered with yesilous hairs.

\section{Dishes made with stinger}

Nettle salad, nettle Waffle, egg nettle roasting, nettle tea, nettle pan pastry with Nettle, nettle spinach dish, nettle potato dish.

\section{Benefits:}

It is very effective in relieving severe headaches.

It has blood cleansing properties and is good for eczema and some fungal diseases (Joshi et al. 2014).

It also has blood-forming properties. It is therefore beneficial in jaundice, anemia and severe blood diseases (Shokrzadeh et al. 2018).

Helps to lower blood sugar. It is very effective against urinary tract infections. It is effective in relieving the pain of kidney stones.

\section{5-Camel Thistle (Silybum marinum)}

It's a family of daisies. It is a one - or two-year-old, 30-100 cm high herbaceous plant that grows in stony and barren fields in fields. It is thin and hooked. July and August flowers are mostly erguvan, sometimes white in color. It smells good when it's old. This smell disappears when it dries.

\section{Benefits:}

Cleans the liver from accumulated toxins (Saller et al. 2001).

Helps to lose weight by burning fat.

Prevents cirrhosis.

Thistle water makes the effect of reducing fever.

\section{6-Teke Beard (Trapogon angustifolium)}

It is a plant growing between $25-35 \mathrm{~cm}$ and flowering in the spring season. It blooms in white, yellow and pink. The gathering season is usually spring and Autumn.

\section{Benefits:}

It is good for vascular stiffness, calcification, lower back and neck pains.

It is good for kidney diseases.

It is used as a vegetable to balance sugar and blood pressure.

Helps to clean blood and remove harmful substances in the body.

Strengthens the digestive system.

Good for liver and stomach ailments (Mohamadi et al. 2015). 


\section{7-Wild mustard (Sinapis arvensis)}

It is a single annual herbaceous plant that can be boylanabilen $30-60 \mathrm{~cm}$. The underparts of its body are generally very forked, stiff, hairy, rarely glabrous. The upper leaves are fragmentary, sessile; the lower leaves are fragmentary, the Leaf parts are larger as they go towards the end, the largest of which is at the most extreme. The flowers are sulphur yellow in colour, the dish leaves are pendulous.

\section{Benefits:}

It has appetizing properties in general.

Makes the stomach easier to digest.

Mustard grass is good for arthritis, lower back and neck pain

Used to increase blood rate.

Mustard is effective in stimulating appetite (Genç and Özhatay 2006)

\section{8-Crowbar (Oenanthe pimpinelloides)}

Spinach family; one or a perennial plant. It may have different color tones depending on the type of soil it grows. Crowbar Yesil may be green, sometimes dark, sometimes reddish in color. The leaves are lined up and a branch emerges from the bottom of each leaf. The lower leaves are short-stemmed and the upper leaves are stemless and can be broad lanceolate, green, brown or brownish.

\section{Benefits:}

Used against skin irritation and depressions.

Protects the body against germs.

Strengthens the immune system.

When used in meals, it opens the appetite of children.

Prevents dandruff and itching on the scalp.

It has a therapeutic effect on stomach ulcers

It is good for liver diseases (Kızılarslan and Özhatay 2012).

\section{9-Gum Grass (Scorzonera hispanica)}

Spinach is a large and very leafy plant in the family. It is a herbaceous plant that grows spontaneously in prairies or gardens. Its leaves are large and numerous, while its roots are branched and less fleshy.

\section{Benefits:}

Effective in stopping cough.

Porridge is good for breast diseases.

Leaves of salad if eaten opens the appetite, digestir the food,

Removes kidney-bladder-spleen pain.

If mixed with rose oil and used, it is effective in relieving headaches (Granica et al. 2015).

\section{0-Bird Grass (Stellaria media)}

Cloves are in the family. It grows widely on roadsides, wall bottoms and gardens. It is a single annual herbaceous plant $10-30 \mathrm{~cm}$ tall. It is very branched and has a crunchy structure, with one side of its light brown body being hairy. Oval-shaped, fleshy and watery leaves, sessile and mutually arranged on 
the body, small reddish, white color and flowers that open continuously from spring to early winter are star-shaped.

\section{Benefits:}

It is diuretic. Makes the kidneys work fast.

Has an effect in removing sputum.

It has the ability to relieve the side effects and pain of rheumatism.

Shows healing effect against hemorrhoids (hemorrhoids).

Removes skin diseases and has the ability to correct human psychology (Ma et al. 2012).

\section{A. Noxious plants growing in the meadows and pastures of şanlıurfa province}

Plants that cause biochemical or physiological changes in the bodies of humans and animals when consumed by humans and animals are called "poisonous plants"(Tükel ve Hatipoğlu, 2001; Balabanlı vd., 2006).

\section{Harmful substances of plants}

\section{- Alkaloids}

They are substances obtained from plants, usually showing strong physiological and pharmacological activity, carrying one or more nitrogen in the ring, showing more or less basic reactions (Töngel and Ayan, 2004). Plants often have more alkaloid matter in organs such as roots, bark, leaves, fruit, seeds. Generally, alkoloids are more soluble in organic solvents than in water. Alkaloids are the most toxic substances in plants. It has more effects on the nervous system and liver. As a result of the effects of the brain and spinal cord with alkaloid intake, nervous system disorders and sudden death may be seen (Ergün et al., 2002).

\section{- Glycosides}

The glycosides group is the first substance released as a result of photosynthesis. In short, glycosides are formed by The Binding of a group other than sugar and carbohydrates with ester bonds. They contain many pigments that dissolve in water and alcohol. Common sugars attached to glycosides are glucose, galactosexylase, and ribose (Baytop, 1963).

\section{- Oxalates}

Oxalates reveal their toxic effects by binding calcium and disrupting the balance of the blood. The number of plants containing these toxic substances at a level that may be harmful is not very high. Excessive intake of oxalate causes kidney damage and, in single stomachs, bone disorders.

\section{Harmful plants}

\section{1-Horsetail grass (Equisetum telmatela Ehrh)}

Is a genus of plants belonging to the family Equisetaceae and is a perennial herb. It grows in wetland meadow areas, along coasts. It is also known by names such as forty lockweed, mule-tailweed and zemberekweed (Al-Snafi 2017).

Contains alkaloid: Equisetin. Glycoside it contains: Saponins

\section{Damages:}

If Horsetail weed is taken together with drugs, it has negative consequences.

It has been determined that thiamine deficiency and electrolyte imbalance may occur in the body as a result of excessive use of horsetail grass. 
If used incorrectly, it can cause skin irritation and itching.

The plant contains a large amount of nicotine.

After consumption, the pulse slows down, muscles relax, causes diseases such as the common cold (Al-Snafi 2017).

\section{2-Hemlock (Conium maculatum )}

It is a plant species belonging to the parsley family and usually grows better in canopy or moist areas. Its length can vary between 1-2 m. The leaves of the plant are large, the flowers are small and splayed.

Contains alkaloid: pyridine( coniine), methylconine, conicerine

Damages: Hemlock is a poisonous plant and it is dangerous to consume it directly. It should be used after being brought to The Shape of mush. Hemlock poison causes the movement nerves to be paralyzed. More than 6 grams of this herb has a lethal effect (Al-Snafi 2016).

\section{3-Shepherd Collapses(Tribulus terrestis)}

It is a plant belonging to the wild cumin family. It is a single annual plant that grows lying in the soil and its flowers are yellow in color. It is a species of plant that grows spontaneously in temperate and tropical regions.

Contains harmful substances: Floeretrin pigment, Resin

\section{Damages:}

If consumed in very small amounts, it causes the accumulation of toxins in the kidney tissues.

Causes sleep problems to be seen.

Causes problems such as inability to urinate.

Taking steroid medication or supplements can destabilize the body (Antonio et al. 2000).

\section{4-Liar lettuce (Lactuca serriola L.)}

Family Asteraceae (Compositae) is dry, nutrient-rich, alkaline and nitrogen containing stony soils can grow. It can also be found in roadsides, spills, field and garden cultures.

\section{Damages:}

Direct removal of wild lettuce causes skin and skin destruction.

Excessive consumption of wild lettuce can cause sweating, shortness of breath and diseases such as vision loss.

People with prostate and urinary problems should stop consuming lettuce. Otherwise, you may be faced with undesirable situations.

Some types of lettuce in people with allergic structure may trigger this problem more.

Wild lettuce can negatively affect the central nervous system. The person to be operated on must stop eating lettuce two weeks in advance (Al-Marzoqi et al. 2015). 


\section{5-Dog Grape (Solanum nigrum L.)}

It belongs to the eggplant family and grows in forests. Its flowers are white but also its fruits are bright and white. The parts used are fruit, leaves and flowers. With the advice of an expert, it can be used in home remedies. When taken in large quantities, the substance atropine, which is a lethal poison, acts (Mohy-Ud-Din et al. 2010).

Glycoside it contains: Solanidine

Damages:

Causes vomiting.

Diarrhea is a problem.

Symptoms include fatigue and fever.

\section{6-Pig Pita (Xanthium strumarium L.)}

It is a single annual plant and is $15-80 \mathrm{~cm}$ tall. The leaves are heart-triangular in shape, randomly segmented or toothed, with short hairs on both faces. It is common in watersides, field cultures, heavy, moist and plant nutrient rich soils. It is a salt-resistant plant. Its fruit is ellipse-shaped and has hookedlike spines.

\section{Contains alkaloid: Xantostruman}

Contains glycoside: Xantostrumarin, Carboxyatractyloside

\section{Damages:}

Pig pita is a host of pathogens that are problematic in many products.

It has been determined that if cattle and sheep eat young plants in areas where they graze, the animals may be poisoned.

In case of eating the leaves, vomiting, muscle spasm, problems such as the emergence of animals and sometimes may cause death Nov.

Animals have been poisoned or even died due to the glycosides of Xanthostrumarin and Carboxyatractyloside contained in the plant.

Causes digestive system problems in animals.

Anemia can be a problem (Kamboj and Saluja 2010).

Many positive or negative effects of self-growing plants in meadows and pastures are observed. Some measures should be taken to address these negative effects.

Table 1. Distinguishing and useful percentages of farmers' useful and harmful plants

\begin{tabular}{cccc}
\hline Variable & Category & Farmer Number & $\begin{array}{c}\text { Percentage of Plant Use } \\
(\boldsymbol{\%})\end{array}$ \\
\hline Amount of Rangeland & $0-100$ decares & 53 & 71.2 \\
Land in the & $100-200$ decares & 31 & 22.7 \\
Mountains (da) & 200 over $>$ decares & 16 & 6.1 \\
& Total & 100 & 100.0 \\
\hline
\end{tabular}

When the land assets of the producers are examined in the research, it is seen that $71.2 \%$ of them have land assets between 0-100 decares. In the study also Şanliurfa province in the Tek Tek and Fatik mountains the knowledge levels and experiences of the producers who collect and preserve useful and harmful plants were examined. Within the scope of the research the majority of the producers 
(58.12\%) stated that they collected safe and healthy useful plants from pastures. It is important that $59.2 \%$ of the producers try new and different plant species, $54.8 \%$ are healthy and $35.2 \%$ are economic In terms of perspective, $31.6 \%$ of them think that environmental protection factors are important, they need to support and protect pastures they expressed.

\section{Solution suggestions}

The plants growing in meadows and pastures should be investigated and the people living in rural areas should be informed by obtaining information about the plants.

Necessary information should be given about the toxic substances contained in the plants growing in meadows pastures and what adverse effects they will have on the animals.

Information should be given about the method of use of beneficial plants grown in meadow pastures (fried, boiled or consumed directly).

It needs to be ensured that the animals graze in a controlled manner.

Agricultural areas, buildings and animal shelter places should not be made without the state's trail in prairie pasture areas.

At certain times officials should go to Meadow pasture areas and check the plant status by conducting inspections.

For the health of animals, it is necessary to recognize plants containing toxic substances, to know their botanical structure and toxic substance content, and to introduce them to producers grazing their animals in pastures.

\section{Conclusion}

Şanliurfa meadows and pastures are damaged pasture management suitable for the region urgently and breeding method studies should be applied. At the stations established in Tek Tek and Fatik mountains naturally grown wild plants It has been determined that it is consumed by the public. Many useful and harmful features of these wild plants grown by learning about this issue should be raised awareness of the public. Plants growing in the meadows and pastures of the region have been seen to decline over time. Weeds have become a problem as a result of early and uncontrolled grazing of animals in meadows and pastures.

Generally, people living in rural areas do not know enough about the plants that grow in meadows and pastures and do not know about these plants can cause significant losses. The aim of this study is to identify some beneficial and harmful plants and to give information about their effects on humans and animals. First of all, weeds grown in these areas must be determined and have detailed information about these herbs. It is important that people know the structure of the plant they will consume, what features, what effect it has and pay attention to them. In order to minimize the damage of poisonous plants in terms of animal health and animal production, the recognition of these plants should not be given to animals at the same time. Extensive studies have to be started for culturing wild plants that grow naturally in meadows and pastures. The people living in rural areas should be informed about the harmful effects of wild plants growing in nature by conducting seminars or information meetings about how and how much these plants can be consumed in daily life.

\section{References}

Al-Marzoqi, A. H., Hussein, H. J., \& Al-Khafaji, N. M. S. (2015). Antibacterial activity of the crude phenolic, alkaloid and terpenoid compounds extracts of Lactuca serriola L. on human pathogenic bacteria. Chemistry and Materials Research, 7(1), 8-10. 
Al-Snafi, A. E. (2016). Pharmacology and toxicology of Conium maculatum-A review. The Pharmaceutical and Chemical Journal, 3(2), 136-142.

Al-Snafi, A. E. (2017). The pharmacology of Equisetum arvense-A review. IOSR Journal of Pharmacy, 7(2), 31-42.

Antonio, J., Uelmen, J., Rodriguez, R., \& Earnest, C. (2000). The effects of Tribulus terrestris on body composition and exercise performance in resistance-trained males. International Journal of Sport Nutrition and Exercise Metabolism, 10(2), 208-215.

Anuradha, J., Muhtari, K., Lone, H., Tripathi, S., \& Sanjeevi, R. (2018) Potentials of Herbs on the Rescue of Influenza Prevention and Control. Journal of Chemistry and Chemical Sciences, Vol.8(5): 898-903.

Arıkan, R., 2007. Research Techniques and Report Preparation. 6.printing, ISBN:975-8784-35-8. Ankara.Baytop, T., 1963. Medicinal And Poisonous Plants Of Turkey. Ismail Akgün Printing House. Istanbul. (http://dergipark.gov.tr/download/article-file/187552)

Barman, D., \& Bhattacharjee, K. (2019). Endophytic Bacteria Associated with Medicinal Plants: The Treasure Trove of Antimicrobial Compounds. In Medically Important Plant Biomes: Source of Secondary Metabolites (pp. 153-187). Springer, Singapore.

Belsky, A. J., \& Gelbard, J. L. (2000). Livestock grazing and weed invasions in the arid West (p. 31). Portland: Oregon Natural Desert Association.

Carvalho, I. S., Teixeira, M., \& Brodelius, M. (2009). Effect of salt stress on purslane and potential health benefits: oxalic acid and fatty acids profile.

Çakır, E. A. (2017). A Comprehensive Review on Ethnomedicinal Utilization of Gymnosperms in Turkey. Eurasian Journal of Forest Science, 5(1), 35-47.

Ergün, A., Çolpan, İ., Yıldız, G., Küçükersan S., Tuncer, D.Ş., Yalçın, S., Küçükersan, M.K. ve Şehu, A., 2002. Feed hygiene and Technology. Ankara University, Faculty of Veterinary Medicine, Department Of Animal Nutrition And Nutrition Diseases,S: 12-55, 318-344. Ankara.

Genç, G. E., \& Özhatay, N. (2006). An ethnobotanical study in Çatalca (European part of Istanbul) II. Turkish Journal of Pharmaceutical Sciences, 3(2), 73-89.

Granica, S., Lohwasser, U., Jöhrer, K., \& Zidorn, C. (2015). Qualitative and quantitative analyses of secondary metabolites in aerial and subaerial of Scorzonera hispanica L.(black salsify). Food Chemistry, 173, $321-331$

Ismail, A., Lamia, H., Mohsen, H., \& Bassem, J. (2012). Chemical composition and herbicidal effects of Pistacia lentiscus L. essential oil against weeds. International Journal of Medicinal and Aromatic Plants, 2(4), 558-565.

Joshi, B. C., Mukhija, M., \& Kalia, A. N. (2014). Pharmacognostical review of Urtica dioica L. International Journal of Green Pharmacy (IJGP), 8(4).

Kamboj, A., \& Saluja, A. K. (2010). Phytopharmacological review of Xanthium strumarium L.(Cocklebur). International Journal of Green Pharmacy (IJGP), 4(3).

Kızılarslan, Ç., \& Özhatay, N. (2012). An ethnobotanical study of the useful and edible plants of İzmit. Marmara Pharmaceutical Journal, 16(3), 194-200.

Lentini, F. (2000). The role of ethnobotanics in scientific research. State of ethnobotanical knowledge in Sicily. Fitoterapia, 71, S83-S88.

Ma, L., Song, J., Shi, Y., Wang, C., Chen, B., Xie, D., \& Jia, X. (2012). Anti-hepatitis B virus activity of chickweed [Stellaria media (L.) Vill.] extracts in HepG2. 2.15 cells. Molecules, 17(7), 8633-8646.

Mohamadi, N., Sharififar, F., Koohpayeh, A., \& Daneshpajouh, M. (2015). Traditional and Ethnobotanical uses of medicinal plants by ancient populations in Khabr and Rouchon of Iran. 
Mohy-Ud-Din, A., Khan, Z. U. D., Ahmad, M., \& Kashmiri, M. A. (2010). Chemotaxonomic value of alkaloids in Solanum nigrum complex. Pakistan journal of botany, 42(1), 653-660.

Perry, L. G., \& Galatowitsch, S. M. (2006). Light competition for invasive species control: a model of cover crop-weed competition and implications for Phalaris arundinacea control in sedge meadow wetlands. Euphytica, 148(1-2), 121-134.

Saller, R., Meier, R., \& Brignoli, R. (2001). The use of silymarin in the treatment of liver diseases. Drugs, 61(14), 2035-2063.

Sargin, S. A. (2015). Ethnobotanical survey of medicinal plants in Bozyazı district of Mersin, Turkey. Journal of Ethnopharmacology, 173, 105-126.

Shokrzadeh, M., Mirshafa, A., Yekta Moghaddam, N., Birjandian, B., \& Shaki, F. (2018). Mitochondrial dysfunction contribute to diabetic neurotoxicity induced by streptozocin in mice: protective effect of Urtica dioica and pioglitazone. Toxicology Mechanisms and Methods, 28(7), 499-506.

Stewart, G. B., \& Pullin, A. S. (2008). The relative importance of grazing stock type and grazing intensity for conservation of mesotrophic 'old meadow'pasture. Journal for Nature Conservation, 16(3), 175-185.

Streeter, C. L., Rumburg, C. B., Hall, T. H., \& Siemer, E. G. (1974). Meadow forage quality, intake, and milk production of cows. Rangeland Ecology \& Management/Journal of Range Management Archives, 27(2), 133-135.

Tögel ve Ayan, 2004. Effects On Some Harmful Plants And Animals Growing In Meadows And Pastures of Samsun Province.

Tükel T. ve R. Hatipoğlu, 2001. On Poisonous Plants And Animals İn Meadow Pastures. (http://www.tarim.gov.tr/arayuz/1/icerik.asp?efl=../cayir_m/3.html\&curdir=lsanal_kutuphanelmakaleler _5lcayir_m\&fl=../cayir_m/4.html.)

Uddin, M., Juraimi, A. S., Hossain, M. S., Un, A., Ali, M., \& Rahman, M. M. (2014). Purslane weed (Portulaca oleracea): a prospective plant source of nutrition, omega-3 fatty acid, and antioxidant attributes. The Scientific World Journal, 2014.

Uygur, F.N., Koch, W., Walter, H., 1986. Description Of Important Weeds In The Wheat-Cotton October System Of Çukurova Region.

Williams, M. C. (1980). Purposefully introduced plants that have become noxious or poisonous weeds. Weed Science, 300-305. 